\title{
Punk Rock and the Value of Auto-ethnographic Writing about Music
}

\author{
Sarah Attfield, University of Technology Sydney
}

Many of the books on punk rock are written from a subjective, personal perspective and come with what could be described as punk attitude. They focus on the experiences of the writers as fans and musicians and contain memoir and interviews alongside varying degrees of critical analysis. These type of texts raise interesting questions; what kinds of critical value have the colloquial and sensationalistic diary entries of Nils Stevenson in Vacant: A Diary of the Punk Years 1976-79 (1999) when compared to a 'scholarly' article on the rhetoric of class by David Simonelli (2002) in the journal Contemporary British History? Can we learn more about the punk scene by knowing that Stevenson used drugs and was romantically involved with Siousxie Sioux, or is it more useful to read the sections on punk in the recent Performing Class in British Popular Music, which aims to 'unravel certain facets of class that appear within punk' (WisemanTrouse 2008: 144)? And what do these texts actually tell us about the music? It is interesting to consider the ways in which popular music is written about. Various genres of popular music are written about from within different fields such as musicology, ethnomusicology, cultural studies and sociology. There are studies based on the textual analysis of songs, analyses of the structure of the music, and those that are focused more on the dynamics of the subcultures, but how many studies of hip hop, pop music, rock music, country music and so on are written from the perspective of fans and musicians? How many of these works offer an insider's view of the music and subculture? And what difference does it make when they do? 
In some respects scholarly writing on punk rock seems like a contradiction. How can music so rooted in anti-establishment sentiment be appropriated into an institutional setting? The auto-ethnographic approach found in many of the studies of punk might be an answer to this question. The writers have used their own experiences as musicians and fans to reflect on and analyse the music and scenes which arguably provides the reader with an 'authentic' and immediate insight. I would suggest that this approach to writing about music, especially anti-establishment music such as punk and hardcoremusic that by its very nature challenges institutions - is potentially more useful to readers interested in understanding the music, the specific circumstances of its creation and how it has inspired and endured.

According to Roy Shuker, since the 1990s there has been an increase in 'confessional memoir' retrospective accounts of music scenes from various eras (2005: 22). He suggests that within studies of popular music, biographies have had an important function and have been particularly useful in the 'construction and maintenance of fandom' (22). Ethnographic approaches to music have also increased and this shift has occurred alongside a growing interest in the study of 'consumption and audiences' (Shuker 2005: 96). This may be linked to the emergence of 'new' ethnography - a style of anthropology favoured by anthropologists such as Kathleen Stewart (1996), which follows on from the work of James Clifford and George Marcus (1986). Clifford and Marcus advocated a style of ethnographic writing that acknowledged its role in the creation of 'true fictions' (1986: 7), and allowed for 'hybrid textual activity' (26) that included the writing of 'insiders' who could 'offer new angles of vision and depths of understanding' through auto-ethnographic accounts (9). This was to be a self-reflexive style of ethnography creating accounts that could be both 'empowered and restricted' (9).

Stewart's approach to ethnography focuses on narratives. She sees stories as 'productive' and suggests that culture needs to be examined through such 'mediating form(s) through which meaning must pass' (1996: 29). For Stewart, ethnography must reject claims to be authoritative and she advocates an ethnography that is capable of 'displacing the rigid discipline of the "subject" and "object" that sets Us apart and leaves Them inert and without agency' (1996: 26). History in this model is an act of 'remembering' (Stewart 1996: 90) and resistant to the kinds of 'master narratives' (96) that 
'speak a war of positions' (97). It is possible that this 'new' ethnography favoured by Stewart may have led to a growing interest in what Karen O'Reilly (2009) calls 'ethnography at home' (110), as ethnographers turn to their own communities as objects of study.

The popularity of ethnographic approaches has also led to an increase in autoethnographic studies of culture. Chan points to trends in ethnography that include 'writings focusing on self' (2008: 31) and a self-reflexivity that allows for 'cultural analysis and interpretation with narrative details' (46) which has the potential to 'enhance cultural understandings' (52). In these 'reader friendly' works, the author has first-hand knowledge of their subject matter and the narratives lead the reader into 'selfexamination' (52) therefore collapsing notions of critical distance. Taking the idea of auto-ethnography a step further is Tami Spry who describes her own practice of performing auto-ethnography as the "convergence of the "autobiographic impulse" and the "ethnographic moment" ... interpreting culture through the self-reflexive and cultural refractions of identity' (2006: 183). Within this type of auto-ethnography the ethnographer weaves qualitative data collected in the field with their own experiences and may include elements of creative non-fiction such as poems and prose and is a combination of analysis and self-observation.

Historian Greg Dening (1996) writes of history as performance and advocates creating history through narratives. For Dening, historians should endeavour to write from experience because participation and active observation is necessary for reflection and to give authority to the words written. And scholars within the discipline of workingclass studies also point to the value of narrative and autobiography in writing history and cultural analysis. British labour historian Tim Strangleman (2005) describes how autobiography has been devalued in some academic circles and dismissed as 'superficial and nostalgic' and unreliable due to the 'production and content (being) driven by popular demand from a general audience, rather than scholarly concerns' (2005: 142). Strangleman makes a case for autobiography as it allows an insight into the 'full depth and breadth' (150) of life and bridges the gap between lived experience and academic culture.

It is possible to critique the personal approach to studying culture though and there are various pitfalls to consider when adopting an auto-ethnographic, autobiographic or 
memoir style of writing about music. There is a danger of overly focusing on the self and therefore becoming self-indulgent at the expense of analysis (Chan 2008). It is also possible to place too much emphasis on narration, again at the expense of analysis and there can be an over-reliance on personal memory which can be unreliable (Chan 2008). And 'subjective involvement' (O'Reilly 2009: 111) may make the study too close to allow for useful critical analysis. These potential limitations need to be acknowledged both by the writer and the reader when approaching a text about punk.

With these ideas in mind it is interesting to note some texts on punk and hardcore. Looking through a list of books on punk it becomes clear that many of the authors were involved in the scene in some way or other, and although most of the accounts of punk have been written retrospectively, music journalists of the time such as Julie Burchill and Tony Parsons were writing about the scene as it happened-notably in their jointauthored 'The Boy Looked at Johnny': The Obituary of Rock and Roll (1978). Punk Rock an Oral History was written by punk musician John Robb (2006), while Punk Diary is the work of DJ and producer George Gimarc (2006). Concert promoter Steven Blush has written American Hardcore: A Tribal History (2006) and many other books have been written from the perspective of fans such as Craig O'Hara's The Philosophy of Punk (2000) and Stephen Colgrave and Chris Sullivans's Punk: A Life Apart (2001). And Pretty Vacant: A History of Punk by Phil Strongman (2007), and Simon Reynolds's Rip it Up and Start Again (2006) and his co-authored The Sex Revolts with Joy Press (1995) include the authors' perspective as fans of the scene under investigation.

The list continues. Rock journalist Greil Marcus has put together his writings on punk in In the Fascist Bathroom (1999), Helen Reddington lays down her punk musician credentials in The Lost Women of Rock Music (2007), and Roger Sabin vouches for the fan status of the authors in Punk Rock: So What? The Cultural Legacy of Punk (1999). In an Australian context there is Stranded by former fanzine creator and Saints fan, Clinton Walker (1996), and Bob Blunt's Blunt (2001), which recounts his experiences as an inner city music fan and fanzine maker. It appears that the position of the author having been involved in the punk and post punk scene as fans, musicians, promoters, and rock journalists is seen to be significant, especially in the marketing of such books.

It is interesting to contrast this approach with that of writing on hip hop. Global 


\title{
Linguistic Flows: Hip Hop Cultures, Youth Identities, and the Politics of Language
}

(Alim, Ibrahim \& Pennycook 2009) is a well put together and a very useful book on hip hop, but while the academic credentials of the writers are listed in the notes on contributors, there are no references to the contributors being fans of the music they are writing about, despite the (slightly unconvincing) 'shout outs' in the acknowledgments. Other important books on hip hop such as Tricia Rose's Black Noise: Rap Music and Black Culture in Contemporary America (1994), despite its obvious engagement with the topic, maintains a distance from the subjects of its analysis. And it is also interesting to note that writing on hip hop and rap music is marketed in a rather dry fashion. The blurb for Adam Krims's 2000 book Rap Music and the Poetics of Identity, states:

\begin{abstract}
This is the first book to discuss in detail how rap music is put together musically. Whereas a great deal of popular music scholarship dismisses music analysis as irrelevant or of limited value, the present book argues that it can be crucial to cultural theory. It is unique for bringing together perspectives from music theory, musicology, cultural studies, critical theory, and communications. It is also the first scholarly book to discuss rap music in Holland, and the rap of Cree Natives in Canada, in addition to such mainstream artists as Ice Cube. (Krims 2000: cover blurb)
\end{abstract}

This can be contrasted with the blurb for Sabin's 1999 Punk Rock: So What?:

\begin{abstract}
It's now over twenty years since punk first pogoed its way into our consciousness. Punk Rock: So What? brings together a new generation of writers, journalists and scholars to provide the first comprehensive assessment of punk and its place in popular music history, culture and myth. Combining new research, methodologies and exclusive interviews, Punk Rock: So What? brings a fresh perspective to the analysis of punk culture, and kicks over many of the established beliefs about the meaning of punk. (Sabin 1999: cover blurb)
\end{abstract}

Some marketers are also guilty of making books on punk sound rather unexciting, although this is more likely the case when the book in question is written in a more detached, academic fashion, such as Stacy Thompson's Punk Productions: Unfinished Business (2004), which takes a Marxist approach and appears to be based on thorough research rather than the author's firsthand accounts.

So what are the reasons for this phenomenon? It is possible that the number of punk texts written by those with first-hand experience can be explained, in part, by the length of time elapsed since punk emerged. With the origins of punk traceable to the very early 1970 s, there has been quite a bit of time for those involved in the scene to become educated and start careers as writers and academics. Authors such as Simon Reynolds, Roger Sabin and Helen Reddington work as professional writers or academics (Reddington currently lectures in music at the University of East London, and Roger 
Sabin lectures in cultural studies at Central St. Martins in London). Because punk's 'moment' was relatively short-lived (although its legacy and influence has continued to the present) some participants in the subculture moved on, gained tertiary educations, and began professional lives. It should be noted, however, that ageing doesn't necessarily lead to a complete withdrawal from a subculture: many fans have maintained their interest in the music (Bennett 2006), and some have remained active within the scene as musicians. Older fans of punk may no longer be seen displaying the 'spectacular' style described by Hebdige (1979), but this is not necessarily an indication of lack of commitment to the music and subculture in general (Bennett 2006). Writing about punk, even from a position as an academic, might therefore be a method of participating in the subculture as an older fan.

Having said this, it is true that hip hop has also been around for a long time (with its origins in the late 1970s and early 1980s), and the artists and fans from the original scene have had a similar amount of time to forge academic careers. Yet fandom does not come across in the texts on hip hop in the same way as in critical works about punk. This may be partly explained by the fan and musician demographic of punk compared to hip hop — with punk fans and musicians generally being white and, therefore, having more access to education and the kind of cultural capital required to develop an academic career. Even though many of the participants in punk culture were working class, they were of the generation (at least in the UK and Australia) for whom higher education was free. And it also possible that while the legacy of punk continues, the scene as it exists today is underground. Hip hop, especially in the USA, is an ongoing and current scene, and participants are involved in more hands on ways as artists and producers. This means that the distancing necessary for reflection has yet to occur. Hip hop artists aren't ready yet to hang up the mic.

Looking inside the books on punk can provide some clues as to why the authors have chosen to incorporate their own experiences into their studies. Roger Sabin states in Punk Rock: So What? that he was conscious of the perspectives of fans and the value of 'history from below' (1999: 6) in choosing what to include in his edited collection of essays. He wanted to create a narrative based on the experiences of those who had actually been there - and this would help to 'relocate' (2) punk and open up new understandings of punk culture and history. In his introduction he points to the 
contributors as having been the 'right age' to have participated as 'musicians, fanzine writers and designers, journalists or simply as fans' (12). And he states that this is in contrast to the 'typical' academic writer who 'takes the stance of an anthropologist exploring an exotic terrain' (12).

Likewise, Simon Reynolds (2006) in Rip it Up and Start Again, explains that part of his reason for writing the book was that he wanted to convey his memory of the post punk era as 'superabundant, a golden age of newness and nowness that created a sensation of moving at high speed into the future' (xii) and because he recognizes how the music and scene impacted on his identity and subsequent choice of career as a music writer.

And Helen Reddington (2007) in The Lost Women of Rock Music suggests that the firsthand experiences of musicians and fans, especially females one, can question the 'given histories' (2) of the period and can amend the omissions found in the documentation of the time. She acknowledges that her work relies on her memories and her involvement as a musician in a punk band. Books such as Reddington's arguably provide a balance between detached, academic writing and the more intimate, immediate recounts of personal experience and the narratives fill some of the gaps in more 'official' histories. In Reddington's case it is the omission of women's experiences that is of particular interest.

So, what are the effects of such an approach? There is something potentially valuable in recounts from those who were involved with the punk scene, and this can be seen when looking at specific examples. In Vacant: A Diary of the Punk Years 1976-79, Nils Stevenson (1999) presents a series of diary entries alongside images of (later) handwritten pieces by other participants in the scene such as Steve Severin, Don Letts and Gaye Advert. The book is illustrated with candid photographs of artists and fans taken by Nils' brother Ray. Although Stevenson's diary entries are rather salacious at times, there is much to learn about the experiences of a young person within a subculture through their own words rather than the detached, anthropological tone as critiqued by Roger Sabin (1999). Stevenson's book captures the atmosphere of the early London punk scene - the decadence, the chaos and the attitude of the young people involved. It gives an insight into the workings of the bands and the ways in which their music was received. The following extract is typical of the diary entries: 
Siouxsie and the Banshees take to the stage at the 100 Club Punk Festival for their first-ever performance. Siouxsie who can't sing, Steve Severin who can't play bass, Marco Pirroni who can play guitar and Sid Vicious who can't play drums, make a wonderful racket for about fifteen minutes, as Siouxsie shouts lyrics from the "Lord's Prayer," "Twist and Shout,"

"Knocking on Heaven's Door," and "Deutschland, Deutschland Uber Alles," while Marco pulls out a catalogue of familiar riffs. It reminds me of Yoko Ono's album "Fly." Everyone hates them. I want to manage them. Bernard won't let the Banshees use the Clash's equipment because of Sid and Siouxsie's swastikas. This incenses Sid who berates Bernard from the stage, calling him a "tight old Jew." (53)

This extract provides the reader with a vivid account of a punk gig and the DIY nature of the music. There is an indication of the randomness of the performance and a sense of how provocative the performers, and the attitudes and behaviours they displayed, were. There is immediacy in this account that would arguably be lost in a more detached academic observation.

\section{Helen Reddington describes herself in the introduction to The Lost Women of Rock}

Music as 'one of the participants in what (she) had thought was going to be a revolution in rock music' (2007: 1). She states that she felt 'indignant that the image of punk that had been set in stone was not what (she) had experienced firsthand' (1), and she wanted to redress the exclusion of women musicians from the histories of punk. Reddington uses a combination of academic analysis, anecdote and oral histories, and the result is an engaging and convincing re-write of the British punk scene from a female perspective. In a section on her own experiences of forming a punk band Reddington points to the importance of including subjective experience. She writes that her memoir is 'typical of young women's experience at this time, and in writing this way (she) is following the precedent of Valerie Walkerdine, who uses her own experiences as a case study in her book Daddy's Girl almost as a direct alternative to the quasi-objective stance taken by some writers' (73). Whilst not as sensationalist as Stevenson, Reddington does paint an interesting picture of her experiences:

In late 1977, the occupants of the basement of the squat I was living in started to become rather noisy. Two girls (they were very young, probably about fourteen) had moved in. They had run away from a children's home. One of them wore a dog-collar, a corset and suspenders, the other wore an old black jacket and a mini skirt, and they both wore lots of black eye makeup. A band had been formed and these girls were the backing vocalists. The name of the band was descriptive rather than ironic: they called themselves The Molesters. The only time the band stopped playing was when Social Services came round looking for the girls ... and when someone wired up their door handles to the mains to attempt to give them a fatal electric shock as they entered their rehearsal room. They remained alive and noisy; at times, we used to bang the floors above their rooms with a hammer to try and shut them up. (74)

According to her account, Reddington's band was formed initially to prove that they 
could do better than the band that lived downstairs. The extract here tells us not only again about the DIY nature of the music and apparent ease of forming a band, but also gives the reader a taste of life for young working-class people (and specifically girls). Here are young teenage runaways living in a squat, dealing with unfriendly neighbours and being chased by the authorities. Again, the first-hand narrative recounts a lived experience and shows what everyday life was like for young women within the scene. There is arguably a potentially empowering effect for the young marginalised women whose position may have been lost within an academic 'outsider' analysis of their subculture.

Steven Blush's American Hardcore: A Tribal History (2001) includes interviews with many artists and fans on the scene at the time and is written and compiled from a fan's perspective. Blush himself was a gig promoter and intimately involved in the US hardcore punk scene which ran from about 1980 to 1986 . The introduction to the book is constructed from interviews with participants and interviewees, such as Kevin Seconds from 7 Seconds and Ian MacKaye from Minor Threat, and these first person accounts provide immediacy. Kevin Seconds describes how he and his friends were influenced by earlier punk bands such as The Ramones and gives an idea of how some of the bands started out:

\footnotetext{
We'd sit on our bed and play along to punk records. The best to play along to was The Ramones' first record - if you turned down one side of your stereo, you could just have the bass and drums and on the other side you have the guitar-almost like having this instructional record. We'd tape record ourselves playing to it. (Seconds 2001: 14)
}

The oral histories in the book create a clear picture of the scene and provide insightful analysis into the music and the culture of American hardcore. The book and subsequent film version (Rachman 2006) explains, via those involved, how the music emerged and evolved from punk, and the reasons for the decline of the American scene. It thus provides a political and social context for the music and fan culture. The film version also incorporates footage from the gigs, which helps recreate the urgency and raw power of the music.

Writing from the first person arguably makes sense when the subject under investigation belongs to a subculture. It is tempting to label such accounts as authentic, but this can be problematic, for what does authentic mean? Suggesting that one version is more 
authentic than another could be exclusionary. Rather than 'authentic,' perhaps Clifford and Marcus's aforementioned 'true fictions' is a preferable term (1986: 7). This takes into account the fabricated nature of ethnography and acknowledges that the cultures being written about are subject to invention through the narrative. Clifford and Marcus note that these fictions are linked to systems of power. Even when writing about a scene that operated at the margins of mainstream society, there are still hierarchies of power involved when one account becomes privileged (published) over another. Many of the authors discussed in this paper do acknowledge the bias of their accounts but see it as inevitable. In Stranded, Clinton Walker begins the book by stating that the 'inevitably personal' history in his book initially made him uneasy (1996: ix). This changed when he realised that he was in a 'privileged position to offer a unique insight' (ix), and his first-hand experience allowed him to 'illustrate the way history can be rewritten' (x). Bob Blunt also points out that his version of the Australian alternative music history in Blunt is 'personal and biased' (2001: xi), and this may be a way around the pitfalls of auto-ethnography. Having said this, the temptation to claim these accounts as authentic remains strong.

Despite the potential problems associated with the unreliability of memory, or the limitations of the focus on a specific field (which may not acknowledge exclusions), I would suggest that to be able to hear from those involved in the music and scenes as insiders is insightful: their accounts helps maintain some of the original and continuing attitude of punk and hardcore. Punk was music that challenged authority and was 'in your face,' and to observe and analyse from a purely academic perspective potentially dampens the original spirit of the scene.

\section{Reference List}

Alim, H. S., Ibrahim, A. \& Pennycook, A. (eds) 2009, Global Linguistic Flows: Hip Hop Cultures, Youth Identities, and the Politics of Language. Routledge, New York \& London.

Bennett, A. 2006, 'Punk's Not Dead: The Significance of Punk Rock for an Older Generation of Fans,' Sociology, vol. 40, no. 1:219-235.

Burchill, J. \& Parsons, T. 1978, 'The Boy Looked at Johnny': The Obituary of Rock and Roll. Pluto Press, London.

Blunt, B. 2001, Blunt: A Biased History of Australian Rock. Prowling Tiger Press, Northcote, Victoria.

Blush, S. 2001, American Hardcore: A Tribal History. Feral House, Los Angeles.

Chan, H. 2008, Autoethnography as Method. Left Coast Press, Walnut Creek, CA.

Clifford, J. \& Marcus, G. E. (eds) 1986, Writing Culture: The Poetics and Politics of Ethnography. University of California Press, Berkeley.

Colgrave S. \& Sullivan, C. 2001, Punk: A Life Apart. London: Cassell. 
Dening, G. 1996, Performances. Melbourne University Press, Melbourne.

Gimarc, G. 2005, Punk Diary 1970-1982. Backbeat Books, San Francisco.

Hebdige, D. 1979, Subculture: The Meaning of Style. Routledge, London.

Krims, A. 2000, Rap Music and the Poetics of Identity. Cambridge University Press, New York.

Marcus, G. 1994, In the Fascist Bathroom: Writings on Punk 1977-1992. London: Penguin.

O'Hara, C. 2001, The Philosophy of Punk: More than Noise. Oakland: AK Press.

O'Reilly, K.n 2009, Key Concepts in Ethnography. Sage, London.

Press, J. \& Reynolds, S. 1995. The Sex Revolts: Gender, Rebellion and Rock and Roll. London: Serpent's Tail.

Rachman, P. (dir.) 2006, American Hardcore: The History of American Punk Rock 1980-1986.

Documentary, AHC productions.

Reddington, H. 2007, The Lost Women of Rock Music: Female Musicians of the Punk Era. Ashgate, , Aldershot.

Reynolds, S. 2006, Rip it Up and Start Again: Postpunk 1978-1984. Penguin, New York.

Robb, J. 2006, Punk Rock: An Oral History. London: Ebury Press.

Rose, T. 1994, Black Noise: Rap Music and Black Culture in Contemporary America. University Press of New England, Hanover, NH.

Sabin, R. 1999, Punk Rock So What? Routledge, New York \& London.

Shuker, R. 2005, Popular Music: The Key Concepts. Routledge, London \& New York.

Simonelli, D. 2002, 'Anarchy, Pop and Violence: Punk Rock Subculture and the Rhetoric of Class,' Contemporary British History, vol. 16, no. 12, 121-144.

Spry, T. 2006, 'Performing Auto-ethnography: An Embodied Methodological Praxis,' in Emergent Methods in Social Research, (eds) S. Hesse-Biber \& P. Leavy. Sage, Thousand Oaks, CA, 183211.

Stevenson, N. 1999, Vacant: A Diary of the Punk Years 1976-79. Thames and Hudson, London.

Stewart, K. 1996, A Space on the Side of the Road: Cultural Poetics in an 'Other' America. Princeton University Press, Princeton.

Strangelman, T. 2005, 'Class Memory: Autobiography and the Art of Forgetting,' in New Working-Class Studies, (eds) J. Russo \& S. Linkon. Cornell University Press, Ithica, 137-152.

Strongman, P. 2008, Pretty Vacant: A History of Punk. Chicago: Chicago Review Press.

Thompson, S. 2004, Punk Productions: Unfinished Business. State University of New York Press, New York.

Walker, C. 1996, Stranded: The Secret History of Australian Independent Music 1977-1991. Pan Macmillan, Sydney.

Wiseman-Trouse, N. 2008, Performing Class in British Popular Music. Palgrave Macmillan, Basingstoke. 